\title{
Pengaruh Iklim Organisasi, Kompetensi, dan Motivasi Kerja Terhadap Kinerja Pegawai BPP Aparatur Sukamandi
}

\author{
Edi Halomoan Irianto \\ Balai Diklat Aparatur Kementerian Kelautan dan Perikanan \\ Jl. Raya Sukamandi KM 2, Ciasem 41256, Subang-Jawa Barat \\ Email: edi_halomoan@yahoo.co.id

\begin{tabular}{ccc}
\hline Diterima & Direvisi & Disetujui \\
$21-01-2020$ & $22-02-2020$ & $24-02-2020$ \\
\hline
\end{tabular}

\begin{abstract}
Abstrak - Manajemen sumber daya manusia sangat memperhatikan proses pekerjaan kinerja pegawai sesuai dengan beban kerja yang ada dalam organisasi dengan menciptakan suasana lingkungan yang harmonis, hubungan pimpinan organisasi dengan kinerja pegawai dan hubungan antar bagian dalam organisasi akan memberi dampak yang sehat dan nyaman diantara pegawai, karena pegawai merupakan salah satu modal penting bagi organisasi. Metode penelitian menggunakan analisis deskriptif dengan skala likert dan analisis verifikatif menggunakan path analysis, hasil yang diperoleh dari peneletian adalah: 1) Nilai hubungan Iklim organisasi dengan Kompetensi pegawai 0,751 (kuat dan searah karena nilainya positif). Nilai hubungan variabel iklim organisasi dengan motivasi kerja 0,681 (kuat dan searah karena nilainya positif). Nilai hubungan variabel kompetensi pegawai dengan motivasi kerja 0,722 (kuat dan searah karena nilainya positif). 2)Hasil analisis jalur secara parsial pengaruh iklim organisasi terhadap kinerja pegawai sebesar 0,296 , pengaruh kompetensi pegawai terhadap kinerja pegawai 0,417 , dan pengaruh motivasi kerja terhadap kinerja pegawai 0,180 . 3) Pengaruh langsung iklim organisasi $8,7 \%$, pengaruh tidak langsung melalui kompetensi pegawai 9,3\%, dan pengaruh tidak langsung melalui motivasi kerja $3,6 \%$ Sehingga total pengaruhnya adalah 21,6\%. Pengaruh langsung kompetensi pegawai $17,4 \%$, pengaruh tidak langsung melalui iklim organisasi 9,3\% dan pengaruh tidak langsung melalui motivasi kerja $5,4 \%$, sehingga total pengaruhnya $32,1 \%$. Pengaruh langsung motivasi kerja $3,2 \%$, sedangkan pengaruh tidak langsung melalui iklim oorganisasi 3,6\% dan pengaruh tidak langsung melalui kompetensi pegawai $5,4 \%$, sehingga total pengaruhnya $12,2 \%$. Hasil perhitungan Koefisien determinasi $\left(\mathrm{r}^{2}\right) \mathbf{6 5 , 9} \%$. Sedangkan faktor lain yang tidak diteliti dan turut mempengaruhi Kinerja Pegawai pada Balai Diklat Aparatur Kementrian Kelautan dan Perikanan Sukamandi $34,5 \%$.
\end{abstract}

\section{Kata Kunci : iklim organisasi, kompetensi karyawan, motivasi kerja dan kinerja karyawan}

Abstract - Human resource management is very concerned about the work process of employee performance in accordance with the workload that exists in the organization by creating a harmonious environment, the relationship between the leadership of the organization and the performance of employees and the relationship between parts within the organization will have a healthy and comfortable impact among employees, because employee is one of the important capital for the organization. The research method uses descriptive analysis with a Likert scale and verification analysis uses path analysis, the results obtained from the research are: 1) The value of the relationship of organizational climate with employee competency is 0.751 (strong and unidirectional because of its positive value). The value of the relationship of organizational climate variables with work motivation 0.681 (strong and unidirectional because the value is positive). The value of the relationship between employee competency variables and work motivation is 0.722 (strong and unidirectional because the value is positive). 2) The results of the path analysis partially influence the organizational climate on employee performance by 0.296, the effect of employee competence on employee performance 0.417 , and the effect of work motivation on employee performance 0.180. 3) The direct influence of the organizational climate is $8.7 \%$, the indirect effect through employee competence is $9.3 \%$, and the indirect effect through work motivation is $3.6 \%$, so the total effect is $21.6 \%$. The direct influence of employee competence is $17.4 \%$, the indirect effect through the organizational climate is $9.3 \%$ and the indirect effect through work motivation is $5.4 \%$, so the total effect is $32.1 \%$. The direct influence of work motivation is $3.2 \%$, while the indirect effect through organizational climate is $3.6 \%$ and the indirect effect through employee competence is $5.4 \%$, so the total effect is $12.2 \%$. The results of the calculation of the coefficient of determination ( $r 2$ ) 65.9\%. While other factors not examined and also influenced the Performance of Employees at the Sukamandi Ministry of Maritime Affairs and Fisheries Apparatus Training Center $34.5 \%$.

Keywords : organizational climate, employee competence, work motivation and employee performance 


\section{PENDAHULUAN}

Pengembangan sumber daya manusia (SDM) dibidang kelautan dan perikanan memiliki peranan strategis dalam mendukung pembangunan kelautan dan perikanan secara keseluruhan. Peran strategis tersebut dilaksanakan melalui kegiatan pendidikan dan pelatihan yang diarahkan untuk mendorong dan mempercepat peningkatan kapasitas sumber daya manusia kelautan dan perikanan, sehingga memiliki kapasitas dan kompetensi yang diharapkan untuk optimalnya pelaksanaan pembangunan kelautan dan perikanan. Balai diklat aparatur KKP memiliki peran strategis dalam meningkatkan aparatur KP dalam unsur pengetahuan, keterampilan, dan sikap. Jumlah aparatur KKP sebanyak 10.475 orang sesuai dengan UU ASN No.5 Tahun 2014, dalam pasalnya disebutkan bahwa dalam 1 (satu) tahun setiap ASN wajib mengikuti diklat (peningkatan kompetensi), pelatihan aparatur negara yang meliputi pelatihan teknis, struktural, pelatihan fungsional, dan pelatihan di lingkungan KKP.

Balai pendidikan dan pelatihan aparatur (BDA) sukamandi yang keberadaannya ditetapkan berdasarkan SK Menteri Kelautan dan Perikanan Nomor.30/KEP/2003, tanggal 20 Agustus 2003, mempunyai tugas melaksanakan bimbingan serta pelatihan teknis dan manajerial di bidang pengembangan aparatur pada lingkup Kementerian Kelautan dan Perikanan. Dari keberadaan BDA Sukamandi ini diharapkan dapat berkinerja dengan menciptakan sumber daya manusia (SDM) Kelautan dan Perikanan yang kompeten sesuai dengan bidang pekerjaan yang di embannya melalui penyelenggaraan kegiatan diklat yang berstandar.

Pegawai atau sumber daya manusia (SDM) pada hakekatnya merupakan unsur utama (mutlak) yang dimiliki organisasi untuk menjadikan suatu organisasi bisa menghasilkan kinerja dan mencapai tujuan yang diharapkan organisasi tersebut. Kinerja pegawai memiliki peranan penting dalam menunjang keberhasilan dan kesuksesan organisasi, apabila kinerja pegawai rendah maka akan berdampak buruk pada kinerja organisasi. Kinerja pegawai dapat dikatakan belum optimal apabila masih ditemukan adanya permasalahan kinerja. Monitoring capaian kinerja PNS Balai Diklat Aparatur Kementerian Kelautan dan Perikanan pada periode Januari s.d. Maret 2018, menunjukkan bahwa kedisiplinan pegawai tergolong rendah, sebanyak 10 orang atau $18 \%$ dari total pegawai melakukan pelanggaran disiplin ketentuan masuk kerja. Penempatan tugas 12 pegawai tidak sesuai dengan latar belakang pendidikan dan spesifikasi jabatan Permasalahan kinerja tersebut diduga berkaitan dengan faktorfaktor yang mempengaruhi kinerja.

Aktivitas yang dilakukan oleh para pegawai dalam menyelesaikan pekerjaannya, tidak terlepas dari siklus manajemen yang diterapkan atau yang melekat pada organisasi. Untuk itu perlu diciptakan suatu kondisi iklim yang harmonis diantara pegawai agar pegawai merasa nyaman dalam melaksanakan tugas pekerjaannya masing-masing, sehingga target yang ditetapkan oleh organisasi dapat dicapai. Konsep the right man on the right place di BDA Sukamandi hingga kini belum tercapai secara maksimal sehingga target pencapaian kerja sering tidak tercapai.

Kurangnya kajian khusus oleh pimpinan atau pegawai dalam organisasi BDA sukamandi dalam membenahi iklim organisasi dinilai kurang, sehingga dorongan untuk dapat bekerja dengan lebih baik guna mencapai efektivitas dan efesiensi belum tercapai dengan baik. Pembenahan kearah yang lebih baik terus diusahakan hingga kini, inovasi dan action terus dilakukan untuk mencapai hasil yang lebih baik di masa yang akan datang, salah satunya dengan mendorong menciptakan iklim organisasi yang dinamis. Walaupun kita tidak dapat melihat dan menyetuh iklim organisasi, kehadirannya bagaikan udara di dalam ruangan yang mengitari dan mempengaruhi segala sesuatu yang terjadi di dalam organisasi.

Fikri Maulidani (2013) dalam penelitiannya menyimpulkan bahwa iklim organisasi berpengaruh signifikan terhadap kompetensi pegawai. Iklim organisasi dan kompetensi pegawai baik secara parsial maupun simultan berpengaruh signifikan terhadap motivasi kerja. Menerima semua fasilitas yang disediakan oleh organisasi berupa fasilitas material yang langsung dapat dirasakan secara nyata terkadang masih dipandang kurang oleh pegawai ketika masuk dalam situasi kerja yang kurang kondusif, merasa di bawah tekanan pekerjaan atau merasa terancam karena jabatan yang dibebankan, oleh karena itu perlu diciptakan suasana atau kondisi bekerja yang nyaman bagi pegawai agar pegawai tetap berada dalam jalur pekerjaan yang seharusnya tanpa merasa terbebani dalam melaksanakan pekerjaannya. Untuk mewujudkan suasana yang harmonis dan kondusif di lingkungan organisasi maka perlu kajian khusus terutama masalah iklim organisasi yang dapat menunjang studi secara empirik hubungan-hubungan dan pengaruh yang signifikan terhadap variabel lain yang berdampak pada kinerja pegawai.

Dalam pelaksanaan tugas dan fungsi BDA sukamandi, maka dukungan kualitas sumber daya manusia (SDM) merupakan salah satu faktor penting untuk meningkatkan produktifitas kinerja suatu organisasi atau instansi. Oleh karena itu, diperlukan sumber daya manusia yang mempunyai kompetensi tinggi karena kompetensi akan dapat mendukung peningkatan prestasi kinerja pegawai. Selama ini banyak instansi pemerintah yang belum mempunyai pegawai dengan kompetensi yang memadai, ini dibuktikan dengan rendahnya produktifitas pegawai dan menurunya kinerja organisasi.

Mengisi struktur organisasi, mengatur personel yang kualifield dibidang yang akan 
ditempati oleh pegawai memerlukan kompetensi dari pegawai sesuai dengan linieritas faktor pendidikan dan pekerjaan yang akan dilakukan, namun demikian masih banyak posisi-posisi pekerjaan dalam organisasi yang ditempati oleh pegawai dengan latar belakang pendidikan yang berbeda sehingga kompetensi pegawai di lingkungan BDA sukamandi dinilai masih belum optimal diperhatikan oleh pimpinan organisasi, terbukti data pendidikan pegawai yang mayoritas berpendidikan SMA/D3, Hal tersebut menunjukkan kemampuan atau kompetensi pegawai masih rendah. Rendahnya kompetensi pegawai sehingga belum dapat menghasilkan kinerja yang optimal.

Sementara untuk mencapai target yang diinginkan organisasi, maka kompetensi menjadi sangat penting. Hal ini dapat dilihat dari hasil penelitian jamaran et al. Dalam (Eddy Yunus, 2012) menyimpulkan bahwa salah satu manfaat utama penggunaan kompetensi dalam organisasi adalah mengerakkan sumber daya manusia ke arah target yang ingin dicapai organisasi melalui penerapan skill dan knowledge sesuai kebutuhan pekerjaan.

Setiap organisasi pemerintahan tak terkecuali BDA Sukamandi mengharapkan suatu keberhasilan, untuk mencapai keberhasilan tersebut membutuhkan adanya pegawai yang berkualitas. Untuk membentuk pegawai yang berkulitas, dibutuhkan dorongan yang kuat dari seorang pimpinan maupun dari pegawai itu sendiri. Dorongan tersebut dapat berupa pemberian motivasi kepada pegawai, yang bertujuan untuk meningkatkan kinerja.

Motivasi suatu proses dimana kebutuhan mendorong seseorang untuk melakukan serangkaian kegiatan yang mengarah tercapainya tujuan tertentu. Motivasi kerja karyawan yang tinggi akan membawa dampak yang positif bagi organisasi dan akan mempengaruhi terciptanya komitmen organisasi (Islam et al., 2015). Melihat arti motivasi, maka orang tanpa mempunyai motivasi, tidak mempunyai hasil kerja yang tinggi.

Kondisi lingkungan kerja yang nyaman dan menyenangkan akan mendukung atau memotivasi pegawai untuk bekerja dengan baik dan benar serta tepat yang pada akhirnya dapat meningkatkan efesiensi kerja yang tinggi yang dapat dijadikan sebagai alat untuk menuju pencapaian tujuan instansi.

\section{Dimensi Iklim Organisasi}

Tagiuri dan Litwin dalam (Wirawan, 2015) mendefinisikan iklim organisasi sebagai "...a relatively enduring quality of the internal environment of an organization that (a) is experienced by its members, (b) influences their behavior, and can be described in terms of the values of a particular set of characteristics (or attributes) of the organization." Menurut Tagiuri dan Litwin, iklim organisasi merupakan kualitas lingkungan internal organisasi yang secara relatif terus berlangsung, dialami oleh anggota organisasi; memengaruhi perilaku mereka dan dapat dilukiskan dalam pengertian satu set karakteristik atau sifat organisasi. Menurut Owen dalam (Wirawan, 2015), iklim organisasi adalah "...study of perceptions that individuals have of various aspects of the environment in the organization" (studi persepsi individu mengenai berbagai aspek lingkungan organisasinya). Stringer dalam (Wirawan, 2015) mendefinisikan iklim organisasi sebagai "...collection and pattern of environmental determinant of aroused motivation" (koleksi dan pola lingkungan yang menentukan munculnya motivasi).

Berdasarkan uraian iklim organisasi tersebut maka dapat disintesiskan bahwa iklim organisasi adalah kualitas lingkungan internal organisasi yang secara relatif terus berlangsung, dialami oleh anggota organisasi; memengaruhi perilaku mereka dan dapat dilukiskan dalam pengertian satu set karakteristik atau sifat organisasi dengan dimensi:
1) Flexibility conformity
2) Responsibility.
3) Standards.
4) Reward.
5) Clarity, dan
6) Tema commitment.

\section{Dimensi Kompetensi Pegawai}

Kompetensi adalah suatu kemampuan untuk melaksanakan atau melakukan suatu pekerjaan atau tugas yang dilandasi atas keterampilan dan pengetahuan serta didukung oleh sikap kerja yang dituntut oleh pekerjaan tersebut. Kompetensi sebagai kemampuan seseorang untuk menghasilkan pada tingkat yang memuaskan di tempat kerja, juga menunjukkan karakteristik pengetahuan dan keterampilan yang dimiliki atau dibutuhkan oleh setiap individu yang memampukan mereka untuk melakukan tugas dan tanggung jawab mereka secara efektif dan meningkatkan standar kualitas professional dalam pekerjaan.

Ada dua istilah yang muncul dari dua aliran yang berbeda tentang konsep kesesuaian dalam pekerjaan. Istilah tersebut adalah "Competency" (kompetensi) yaitu deskripsi mengenai perilaku, dan "Competence" (kecakapan) yang merupakan deskripsi tugas atau hasil pekerjaan. (R. Palan, 2007)

Walau perbedaan arti kedua istilah tersebut diterima secara umum, namun penggunaannya masih sering dipertukarkan, yang menyebabkan setiap orang memiliki pengertian yang berbedabeda. Umumnya orang menggunakan istilah kompetensi dan sejenisnya menciptakan pengertian sendiri sesuai dengan kepentingannya. Komentar Zamkee (1982) yang dikutip oleh (R. Palan, 2007) mengatakan bahwa "Kompetensi (competence), model kompetensi dan pelatihan berbasis kompetensi merupakan kata yang bisa diartikan 
beragam mengikuti pendefinisiannya. Perbedaan makna tersebut bukan berasal dari kebodohan atau ketamakan pasar, tapi dari beberapa prosedur mendasar dan perbedaan filosofis diantara mereka yang berlomba untuk mendefinisikan dan membentuk konsep tersebut dan menetapkan model bagi kita yang akan menggunakan kompetensi dalam upaya sehari-hari. (R. Palan, 2007) Kompetensi merujuk kepada karakterisitk yang mendasari perilaku yang menggambarkan motif, karakteristik pribadi (ciri khas), konsep diri, nilai-nilai, pengetahuan atau keahlian yang dibawa seseorang yang berkinerja unggul (superior performer) di tempat kerja. Menurut (Veithzal Rivai \& A.F.M Basri, 2005) kinerja adalah hasil atau tingkat keberhasilan seseorang secara keseluruhan selama periode tertentu di dalam melaksanakan tugas dibandingkan dengan berbagai kemungkinan, seperti standar hasil kerja, target atau sasaran atau kriteria yang telah ditentukan terlebih dahulu dan telah disepakati bersama.

Lasmahadi dalam (Prayitno, 2002), mengatakan bahwa kompetensi didefinisikan sebagai aspek pribadi dari seorang pegawai yang memungkinkan dia untuk mencapai kinerja yang superior. Aspek-aspek pribadi termasuk sifat, motifmotif, sistem nilai, sikap pengetahuan, dan keterampilan. Kompetensi-kompetensi akan mengarahkan tingkah laku, sedangkan tingkah laku akan menghasilkan kinerja. Kompetensi berdasarkan Peraturan Pemerintah Nomor 100 Tahun 2000, adalah kemampuan dan karakteristik yang dimiliki oleh seorang PNS berupa pengetahuan, keterampilan dan atau sikap perilaku yang diperlukan dalam pelaksanaan tugas jabatannya.

Berdasarkan uraian kompetensi pegawai tersebut maka dapat disintesiskan bahwa kompetensi pegawai adalah suatu kemampuan untuk melaksanakan atau melakukan suatu pekerjaan atau tugas yang dilandasi atas keterampilan dan pengetahuan serta didukung oleh sikap kerja yang dituntut oleh pekerjaan tersebut dengan dimensi: 1) Task achievement, 2) Relationship, 3) Personal attribute, 4) Managerial dan 5) Leadership.

\section{Dimensi Motivasi Kerja}

Istilah motivasi berasal dari kata Latin "movere" yang berarti dorongan atau menggerakkan. Motivasi mempersoalkan bagaimana cara mengarahkan daya dan potensi agar bekerja mencapai tujuan yang ditentukan. Menurut Vroom dalam (Ngalim Purwanto, 2006), motivasi mengacu kepada suatu proses mempengaruhi pilihan-pilihan individu terhadap bermacam-macam bentuk kegiatan yang dikehendaki.

Kemudian John P. Campbell, dkk dalam (Ngalim Purwanto, 2006) mengemukakan bahwa motivasi mencakup di dalamnya arah atau tujuan tingkah laku, kekuatan respons, dan kegigihan tingkah laku. Di samping itu, istilah tersebut mencakup sejumlah konsep dorongan (drive), kebutuhan (need), rangsangan (incentive), ganjaran (reward), penguatan (reinforcement), ketetapan tujuan (goal setting), harapan (expectancy), dan sebagainya.

Menurut (Hamzah B. Uno, 2008), kerja adalah sebagai 1) aktivitas dasar dan dijadikan bagian esensial dari kehidupan manusia, 2) kerja itu memberikan status, dan mengikat seseorang kepada individu lain dan masyarakat, 3) pada umumnya wanita atau pria menyukai pekerjaan, 4) moral pekerja dan pegawai itu banyak tidak mempunyai kaitan langsung dengan kondisi fisik maupun materiil dari pekerjaan, 5) insentif kerja itu banyak bentuknya, diantaranya adalah uang.

Motivasi kerja merupakan motivasi yang terjadi pada situasi dan lingkungan kerja yang terdapat pada suatu organisasi atau lembaga. Keberhasilan dan kegagalan pendidikan memang sering dikaitkan dengan motivasi kerja guru. Pada dasarnya manusia selalu menginginkan hal yang baik-baik saja, sehingga daya pendorong atau penggerak yang memotivasi semangat kerjanya tergantung dari harapan yang akan diperoleh mendatang jika harapan itu menjadi kenyataan maka seseorang akan cenderung meningkatkan motivasi kerjanya.

Berdasarkan uraian motivasi kerja di atas maka dapat disintesiskan bahwa motivasi kerja adalah daya dorong atau daya gerak yang membangkitkan dan mengarahkan perilaku pada suatu perbuatan atau pekerjaan pada upaya-upaya nyata untuk mencapai tujuan yang telah ditetapkan dengan dimensi: 1) Tanggung jawab dalam melakukan kerja. 2) Prestasi yang dicapainya, 3) Pengembangan diri, dan 4) Kemandirian dalam bertindak.

\section{Dimensi Kinerja Pegawai}

Menurut (Mangkunegara, AA., 2006); kinerja dapat didefinisikan sebagai hasil kerja secara kualitas dan kuantitas yang dapat dicapai oleh seseorang pegawai dalam melaksanakan tugas sesuai dengan tanggungjawab yang diberikan kepadanya.

Kinerja merupakan istilah yang berasal darikata Job Performance atau Actual Performance (prestasi kerja atau prestasi sesungguhnya dicapai seseorang). Kinerja (prestasi kerja) adalah "hasil kerja" (Mangkunegara, 2006:9). Kinerja merupakan hasil kerja baik kualitas maupun kuantitas yang dihasilkan pegawai atau secara kualitas dan kuantitas yang dicapai seorang pegawai dalam melaksanakan tugasnya sesuai dengan tanggung jawab yang diberikan kepadanya perilaku nyata yang ditampilkan sesuai dengan tanggung jawab yang diberikan kepadanya.

(T. Hani Handoko, 2001), mendefinisikan penilaian prestasi kerja (performance appraisal) 
adalah "proses melalui nama organisasi-organisasi mengevaluasi atau menilai prestasi kerja pegawai".

Penilaian kinerja adalah proses suatu organisasi mengevaluasi atau menilai kerja pegawai. Apabila penilaian prestasi kerja dilaksanakan dengan baik, tertib, dan benar akan dapat membantu meningkatkan motivasi berprestasi sekaligus dapat meningkatkan loyalitas para anggota organisasi yang ada di dalam-nya, dan apabila ini terjadi akan menguntungkan organisasi itu sendiri. Oleh karena itu penilaian kinerja perlu dilakukan secara formal dengan kriteria-kriteria yang telah ditetapkan oleh organisasi secara obyektif.

Penilaian kinerja adalah alat yang berfaedah tidak hanya untuk mengevaluasi kerja dari para pegawai, tetapi juga untuk mengembangkan dan memotivasi kalangan pegawai. Dalam penilaian kinerja tidak hanya semata-mata menilai hasil fisik, tetapi pelaksanaan pekerjaan secara keseluruhan yang menyangkut berbagai bidang seperti kemampuan, kerajinan, disiplin, hubungan kerja atau hal-hal khusus sesuai bidang tugasnya semuanya layak untuk dinilai (Henry Simamora, 2006).

Berdasarkan uraian kinerja pegawai diatas maka dapat disintesiskan bahwa kinerja pegawai adalah hasil kerja secara kualitas dan kuantitas yang dapat dicapai oleh seseorang pegawai dalam melaksanakan tugas sesuai dengan tanggungjawab yang diberikan kepadanya dengan Dimensi: 1) faktor personal, 2) faktor kepemimpinan, 3) faktor tim, 4) faktor system dan 5) faktor kontekstual.

\section{METODE PENELITIAN}

Penelitian ini dilakukan di Balai Diklat Aparatur Kementerian Kelautan dan Perikanan. Responden penelitian ini adalah seluruh pegawai di Balai Diklat Aparatur (BDA) berstatus PNS berjumlah 55 orang. Responden dikelompokkan menjadi 2 kategori berdasarkan tingkat pendidikan. Kategori pendidikan tinggi adalah pegawai yang berpendidikan Magister (S2) s.d Ahli Madya (D3) dan kategori pendidikan rendah adalah pegawai yang berpendidikan SMA s.d SD.

Analisis data dilakukan pada masing- masing kelompok kategori pendidikan. Jenis data yang digunakan adalah data primer dan data sekunder. Data primer diperoleh melalui penyebaran kuesioner ke responden yang diukur menggunakan Skala Likert 1 sampai 5, sedangkan data skunder didapatkan dari dokumen penilaian prestasi kerja pegawai, struktur organisasi, sistem informasi dan manajemen kepegawaian (simpeg) dan presensi pegawai. Metode pengolahan dan analisis data menggunakan SPSS Versi 19. Analisis deskripsi responden menunjukkan bahwa tingkat pendidikan responden sangat beragam mulai dari SD sampai dengan S2. Responden yang berpendidikan S3 sebanyak 1 orang, S2 sebanyak 17 orang, S1/Sederajat sebanyak 9 orang, D3/Sederajat sebanyak 3 orang, SMA/Sederajat sebanyak 18 orang, SMP sebanyak 4 orang dan SD sebanyak 3 orang. Berdasarkan data tersebut pegawai yang masuk kategori pendidikan tinggi berjumlah 30 orang dan pegawai yang masuk kategori pendidikan rendah sebanyak 25 orang.

\section{Paradigma Penelitian}

Berdasarkan latar belakang permasalahan, maka perlu dilakukan analisis pengaruh iklim organisasi, kompetensi, dan motivasi kerja terhadap kinerja pegawai. Pendidikan dijadikan sebagai pemoderasi dalam penelitian ini karena tingkat pendidikan diasumsikan mempengaruhi persepsi pegawai terhadap pembentukan iklim organisasi dalam mempengaruhi kepuasan kerja dan kinerja. Selain itu pendidikan juga memiliki pengaruh yang signifikan terhadap kinerja pegawai. Hal ini dibuktikan dalam penelitian Patiran (2010) yang menyatakan bahwa pendidikan berpengaruh positif terhadap kinerja. Tujuan penelitian adalah: 1) Untuk mengkaji hubungan iklim organisasi, kompetensi pegawai dan motivasi kerja di Balai Pendidikan dan Pelatihan Aparatur Kementerian Kelautan Perikanan. 2) Untuk mengkaji pengaruh parsial iklim organisasi, kompetensi pegawai, dan motivasi kerja terhadap kinerja pegawai di Balai Pendidikan dan Pelatihan Aparatur Kementerian Kelautan Perikanan.3) Untuk mengkaji pengaruh simultaniklim organisasi, kompetensi pegawai, dan motivasi kerja terhadap kinerja pegawai di Balai Pendidikan dan Pelatihan Aparatur Kementerian Kelautan Perikanan.

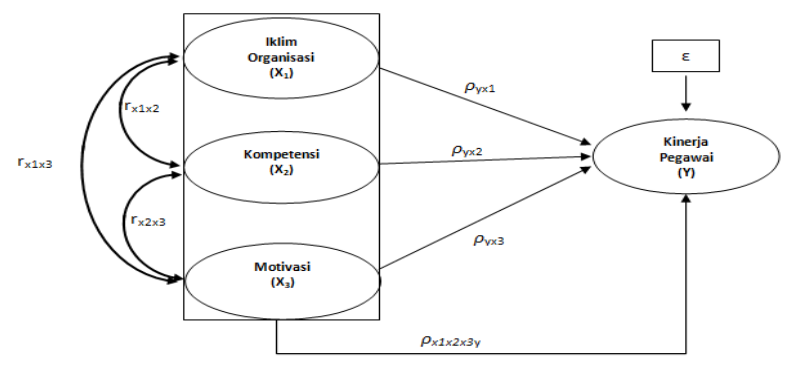

Gambar 1 Model pengaruh iklim organisasi, kompetensi pegawai dan motivasi kerja terhadap kinerja pegawai.

\section{HASIL DAN PEMBAHASAN}

\section{Uji Validitas dan Reliabilitas}

1. Uji Validitas dan Reliabilitas Iklim Organisasi Berdasarkan pengolahan data validitas instrument iklim organisasi diperoleh semua item nilai Corrected Item-Total Correlation > dari 0,3 maka semua item instrument Iklim Organisasi valid, artinya data instrument iklim organisasi layak digunakan untuk penelitian. 
Tabel 1 Uji Reliabilitas Variabel Iklim organisasi (X1)

Reliability Statistics

\begin{tabular}{|c|c|c|}
\hline Cronbach's Alpha & $\begin{array}{c}\text { Cronbach's Alpha } \\
\text { Based on Standardized } \\
\text { Items }\end{array}$ & N of Items \\
\hline .868 & .870 & 40 \\
\hline
\end{tabular}

Sumber : Data Kajian, dianalisis, 2016

Reliabilitas variabel Iklim organisasi adalah 0,868> 0,60 maka semua data instrument variable Iklim organisasi reliabel dan layak digunakan sebagai alat penelitian.

\section{Uji Validitas dan Reliabilitas Kompetensi} Pegawai

Berdasarkan pengolahan data validitas instrument Kompetensi Pegawai BDA Kementrian Kelautan dan Perikanan diperoleh nilai Corrected Item-Total Correlation > 0,3 maka semua item instrument Kompetensi Pegawai valid, artinya data kompetensi pegawai layak digunakan untuk penelitian.

Tabel 2 Uji Reliabilitas Variabel Kompetensi Pegawai $\left(\mathrm{X}_{2}\right)$

Reliability Statistics

\begin{tabular}{|c|c|c|}
\hline Cronbach's Alpha & $\begin{array}{l}\text { Cronbach's Alpha } \\
\text { Based on } \\
\text { Standardized Items }\end{array}$ & $\mathrm{N}$ of Items \\
\hline .954 & .955 & 40 \\
\hline
\end{tabular}

Sumber : Data Kajian, dianalisis, 2016

Reliabilitas variable Kompetensi Pegawai adalah $0,954>0,60$ maka semua data instrument variable Kompetensi Pegawai reliabel dan dapat digunakan sebagai alat penelitian.

\section{Uji Validitas dan Reliabilitas Motivasi Kerja}

Berdasarkan pengolahan data validitas instrument Motivasi Kerja diperoleh nilai Corrected Item-Total Correlation > dari 0,3 maka semua item instrument Motivasi Kerja valid, artinya data instrument motivasi kerja layak digunakan penelitian.

Tabel 3 Uji Reliabilitas Variabel Motivasi Kerja (X3)

Reliability Statistics

\begin{tabular}{|c|c|c|}
\hline Cronbach's Alpha & $\begin{array}{c}\text { Cronbach's Alpha } \\
\text { Based on } \\
\text { Standardized Items }\end{array}$ & N of Items \\
\hline .901 & .902 & 40 \\
\hline
\end{tabular}

Sumber : Data Kajian, dianalisis, 2016

Reliabilitas variable Motivasi Kerja adalah 0,901 > 0,30 maka semua data instrument dinilai reliabel dan dapat digunakan sebagai alat penelitian.

4. Uji Validitas dan Reliabilitas Kinerja Pegawai Berdasarkan pengolahan data validitas instrument Kinerja Pegawai diperoleh nilai
Cronbach's Alpha if Item Deleted >0,3 maka semua item instrument Kinerja Pegawai valid, artinya data instrument kinerja pegawai layak untuk digunakan penelitian.

Tabel 4 Uji Reliabilitas Variabel Kinerja Pegawai (Y)

Reliability Statistics

\begin{tabular}{|c|c|c|}
\hline Cronbach's Alpha & $\begin{array}{l}\text { Cronbach's Alpha } \\
\text { Based on } \\
\text { Standardized Items }\end{array}$ & $\mathrm{N}$ of Items \\
\hline .905 & .905 & 40 \\
\hline
\end{tabular}

Sumber: Data Kajian, dianalisis, 2016

Reliabilitas variable Kinerja Pegawai adalah $0,905>0,30$ maka semua data instrument variable Kinerja Pegawai reliable dan dapat digunakan sebagai alat penelitian.

\section{Analisis Jalur (Path Analysis)}

Analisis Jalur digunakan untuk mengetahui apakah data mendukung teori, yang secara a-priori dihipotesiskan, yang mencakup kaitan struktural antar variabel terukur. Analisis Jalur atau yang lebih dikenal luas sebagai Path Analysis merupakan suatu metode pendekomposisian korelasi kedalam bagian-bagian yang berbeda untuk menginterpretasikan suatu pengaruh (effect). Dalam analisis jalur yang distandarkan korelasi dapat dipecah kedalam komponen-komponen struktural (kausal) dan nonstruktural (nonkausal) didasarkan teori yang dinyatakan dalam diagram jalur.

\section{Koefisien Korelasi}

Perhitungan koefisien korelasi menggunakan analisis korelasi Pearson Product Moment, dilakukan guna mengetahui seberapa kuat hubungan antara beberapa variabel independen yang diteliti. Perhitungan koefisien korelasi menggunakan program SPSS, dengan hasil seperti yang tertera pada tabel berikut ini ;

Tabel 5 Hubungan iklim organisasi, kompetensi pegawai dan motivasi kerja.

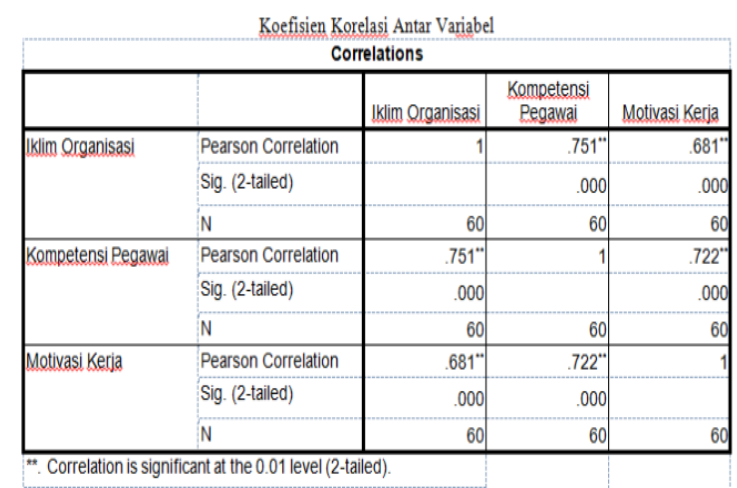

Sumber : Data Kajian, dianalisis, 2016 
Terdapat hubungan yang positif antara variabel bebas dalam penelitian. Untuk jelasnya besaran koefisien. Dapat dilihat pada gambar berikut ini:

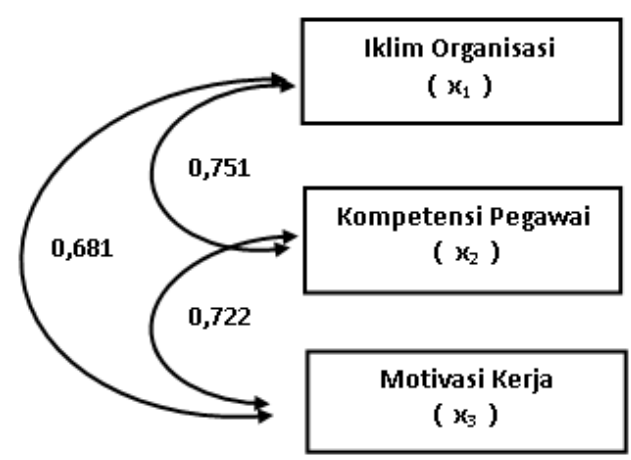

Gambar 2 Model Hubungan iklim organisasi, kompetensi pegawai dan motivasi kerja.

\section{Koefisien Jalur}

Berdasarkan hasil perhitungan dengan menggunakan program SPSS v20 diperoleh besaran koefisien jalur seperti yang dijelaskan pada tabel di bawah ini:

Tabel 6 Nilai Koefisien Jalur

\begin{tabular}{|c|c|c|c|c|c|c|}
\hline \multicolumn{7}{|c|}{ Coefficients $^{\mathrm{a}}$} \\
\hline \multirow{2}{*}{\multicolumn{2}{|c|}{ Model }} & \multicolumn{2}{|c|}{ Unstandardized Coefficients } & \multirow{2}{*}{\begin{tabular}{|c|}
$\begin{array}{c}\text { Standardized } \\
\text { Coefficients }\end{array}$ \\
Beta
\end{tabular}} & \multirow[b]{2}{*}{$t$} & \multirow[b]{2}{*}{ Sig. } \\
\hline & & $B$ & Std. Error & & & \\
\hline \multirow[t]{4}{*}{1} & (Constant) & 32.879 & 12.493 & & 2.632 & .010 \\
\hline & |klim Organisasi & .387 & .114 & .296 & 3.393 & .001 \\
\hline & Kompetensi Pegawai & .592 & .112 & .417 & 5.304 & .000 \\
\hline & Motivasi Kerja & .247 & .113 & .180 & 2.187 & .031 \\
\hline
\end{tabular}

Sumber : Data Kajian, dianalisis, 2016

Berdasarkan tabel diatas diperoleh besaran koefisien jalur antar variabel penelitian yang dapat di lihat pada tabel sebagai berikut :

Tabel 7 Hasil Perhitungan Jalur

\begin{tabular}{|l|c|}
\hline \multicolumn{1}{|c|}{ Variabel } & Koefisien Jalur \\
\hline Iklim Organisasi $\left(\mathrm{X}_{1}\right)$ & 0.296 \\
\hline Kompetensi Pegawai $\left(\mathrm{X}_{2}\right)$ & 0.417 \\
\hline Motivasi Kerja $\left(\mathrm{X}_{3}\right)$ & 0.180 \\
\hline
\end{tabular}

Sumber : Data Kajian, dianalisis, 2016

Tabel 7 menggambarkan hasil perhitungan jalur, bahwa variabel $X_{1}$ mempunyai koefisien jalur sebesar 0,296, Variabel $\mathrm{X}_{2}$ mempunyai koefisien jalur sebesar 0,417 dan Variabel $X_{3}$ mempunyai koefisien jalur sebesar 0,180.

Hasil analisis jalur variable iklim organisasi, kompetensi pegawai dan motivasi kerja terhadap
Kinerja Pegawai dapat dijelas pada gambar di bawah ini:

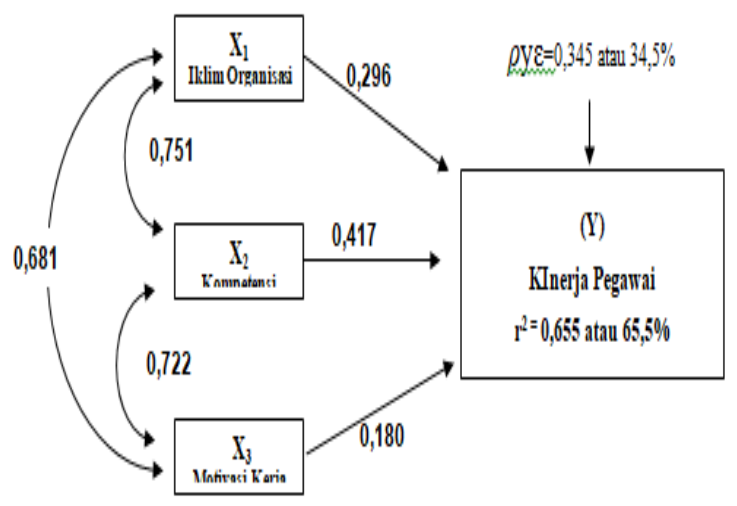

Gambar 3 Analisis Jalur pengaruh iklim organisasi, kompetensi pegawai dan motivasi kerja terhadap kinerja pegawai.

Berdasarkan gambar 3 maka diperoleh persamaan jalur sebagai berikut ;

$$
Y=0,296 X_{1}+0,417 X_{2}+0,180 X_{3}+\varepsilon
$$

Dimana :

$$
\begin{array}{ll}
\mathrm{Y} & =\text { Kinerja Pegawai } \\
\mathrm{X}_{1} & =\text { Iklim Organisasi } \\
\mathrm{X}_{2} & =\text { Kompetensi Pegawai } \\
\mathrm{X}_{3} & =\text { Motivasi Kerja }
\end{array}
$$

Besarnya pengaruh dari masing-masing variabel bebas terhadap variabel terikat baik pengaruh langsung (Direct Effect) maupun pengaruh tidak langsung (Indirect Effect) dapat di lihat pada tabel

\begin{tabular}{|c|c|c|c|}
\hline Variabel & \multicolumn{3}{|c|}{ Pengaruh Langsung } \\
\hline Iklim Organisasi & \multicolumn{3}{|c|}{$(0,296 \times 0,296) \times 100 \%=0,087$ atau $8,7 \%$} \\
\hline Kompetensi & \multicolumn{3}{|c|}{$(0,417 \times 0,417) \times 100 \%=0,174$ atau $17,4 \%$} \\
\hline Motivasi Kerja & \multicolumn{3}{|c|}{$(0,180 \times 0,180) \times 100 \%=0,032$ atau $3,2 \%$} \\
\hline \multirow[b]{2}{*}{ Variabel } & \multicolumn{3}{|c|}{ Pengaruh Tidak Langsung } \\
\hline & Iklim Organisasi & $\begin{array}{l}\text { Kompetensi } \\
\text { Pegawai }\end{array}$ & Motivasi Kerja \\
\hline Iklim Organisasi & - & $\begin{array}{c}(0,296 \times 0,417 \times 0,751) \\
\times 100 \%\end{array}$ & $\begin{array}{c}(0,296 \times 0,180 \times 0,681) \\
\times 100 \%\end{array}$ \\
\hline Kompetensi & $\begin{array}{c}(0,296 \times 0,417 \times 0,751) \\
\times 100 \% \\
\end{array}$ & . & $\begin{array}{c}(0,417 \times 0,180 \times 0,722) \\
\times 100 \% \\
\end{array}$ \\
\hline Motivasi Kerja & $\begin{array}{c}(0,296 \times 0,180 \times 0,681) \\
\times 100 \%\end{array}$ & $\begin{array}{c}(0,417 \times 0,180 \times 0,722) \\
\times 100 \%\end{array}$ & - \\
\hline
\end{tabular}
berikut ini:

Tabel 8 Perhitungan Pengaruh langsung dan pengaruh tidak langsung Variabel bebas terhadap variabel terikat

Sumber : Data Kajian, dianalisis, 2016 
Hasil perhitungan pengaruh langsung dan pengaruh tidak langsung di atas apabila dibuat secara ringkas, hasilnya adalah sebagai berikut:

Tabel 9 Rekapitulasi Pengaruh langsung dan pengaruh tidak langsung Variabel bebas terhadap variabel terikat

\begin{tabular}{|c|c|c|c|c|c|c|}
\hline \multirow[b]{2}{*}{ Variabel } & \multirow{2}{*}{$\begin{array}{l}\text { Pengaruh } \\
\text { Langsung }\end{array}$} & \multicolumn{4}{|c|}{ Pengaruh Tidak Langsung } & \multirow{2}{*}{$\begin{array}{c}\text { Total } \\
\text { Pengaruh }\end{array}$} \\
\hline & & $x_{1}$ & $x_{2}$ & $x_{3}$ & Total & \\
\hline Iklim Organisasi & $8,7 \%$ & & $9,3 \%$ & $3,6 \%$ & $12,9 \%$ & $21,2 \%$ \\
\hline Kompetensi & $17,4 \%$ & $9,3 \%$ & & $5,4 \%$ & $14,7 \%$ & $32,1 \%$ \\
\hline Motivasi Kerja & $3,2 \%$ & $3,6 \%$ & $5,4 \%$ & & $9 \%$ & $12,2 \%$ \\
\hline \multicolumn{6}{|c|}{ Total Pengaruh $\mathrm{X}_{1}, \mathrm{X}_{2}, \mathrm{X}_{3} \mathrm{Ke} \mathrm{Y}$} & $65,5 \%$ \\
\hline \multicolumn{6}{|c|}{ Total Pengaruh Variabel Lain (di luar penelitian) } & $34,5 \%$ \\
\hline
\end{tabular}

Sumber : Data Kajian, dianalisis, 2016

1. Penelitian Hubungan Iklim Organisasi Kompetensi Pegawai, dan Motivasi Kerja pada Balai Diklat Aparatur Kementrian Kelautan dan Perikanan Sukamandi.

Hubungan antara variabel iklim organisasi $\left(\mathrm{X}_{1}\right)$ dengan kompetensi pegawai $\left(\mathrm{X}_{2}\right)$ didapat nilai sebesar 0,751 sehingga apabila dikonsultasikan dengan tabel interpretasi nilai $r$ (korelasi), mempunyai tingkat hubungan yang kuat dan searah karena nilainya positif, dapat diartikan apabila Iklim Organisasi $\left(\mathrm{X}_{1}\right)$ naik sebesar satu satuan, maka diikuti dengan kenaikan besaran Kompetensi Pegawai $\left(\mathrm{X}_{2}\right)$ sebesar 0,751satuan. Hubungan antara variabel iklim organisasi $\left(\mathrm{X}_{1}\right)$ dengan motivasi kerja $\left(\mathrm{X}_{3}\right)$ didapat nilai sebesar 0,681. Sehingga apabila dikonsultasikan dengan tabel interpretasi nilai $r$, mempunyai tingkat hubungan yang kuat dan searah karena nilainya positif, dapat diartikan apabila Iklim Organisasi $\left(\mathrm{X}_{1}\right)$ naik sebesar satu satuan, maka di ikuti oleh kenaikan Peran Kepemimpinan $\left(\mathrm{X}_{3}\right)$ sebesar 0,681 satuan.

Hubungan antara variabel kompetensi pegawai (X2) dengan motivasi kerja $\left(\mathrm{X}_{3}\right)$ didapat nilai sebesar 0,722 Sehingga apabila dikonsultasikan dengan tabel interpretasi nilai $r$ (korelasi), mempunyai tingkat hubungan yang Kuat dan searah karena nilainya positif, dapat diartikan apabila besaran Kompetensi Pegawai $\left(\mathrm{X}_{2}\right)$ naik sebesar satu satuan, maka akan diikuti oleh kenaikan besaran Motivasi Kerja $\left(\mathrm{X}_{3}\right)$ sebesar $\mathbf{0 , 7 2 2}$ satuan.

2. Pengaruh secara parsial Iklim Organisasi, Kompetensi Pegawai, dan Motivasi Kerja terhadap Kinerja Pegawai pada Balai Diklat Aparatur Kementrian Kelautan dan Perikanan Sukamandi.
Hasil perhitungan jalur variabel $\mathrm{X}_{1}$ mempunyai koefisien jalur sebesar 0,296, Variabel $\mathrm{X}_{2}$ mempunyai koefisien jalur sebesar 0,417 dan Variabel $\mathrm{X}_{3}$ mempunyai koefisien jalur sebesar 0,180 .

Untuk pengaruh iklim organisasi $\left(\mathrm{X}_{1}\right)$ secara parsial terhadap kinerja pegawai (Y), dengan tingkat signifikansi $(\alpha)=5 \%$ dan degree of freedom $(\mathrm{df})=(\mathrm{n}-2)=132-2=130$ sehingga diperoleh $t_{\text {tabel }}$ 1.65666. Nilai sig. $(0,001)<\alpha$ $(0,05)$ dan $t_{\text {hitung }}(3,393)>t_{\text {tabel }}(1.65666)$ sehingga $\mathrm{H}_{0}$ ditolak. Dengan demikian terdapat pengaruh secara parsial iklim organisasi terhadap kinerja pegawai.

Pengaruh kompetensi pegawai $\left(\mathrm{X}_{2}\right)$ secara parsial terhadap kinerja pegawai (Y), dengan tingkat signifikansi $(\alpha)=5 \%$ dan degree of freedom $(\mathrm{df})=(\mathrm{n}-2)=132-2=130$ sehingga diperoleh $t_{\text {tabel }}$ 1.65666. Nilai sig. $(0,00)<\alpha$ $(0,05)$ dan $t_{\text {hitung }}(5,034)>t_{\text {tabel }}(1.65666)$ sehingga $\mathrm{H}_{0}$ ditolak. Dengan demikian terdapat pengaruh secara parsial kompetensi pegawai terhadap kinerja pegawai.

Untuk pengaruh motivasi kerja $\left(\mathrm{X}_{3}\right)$ secara parsial terhadap kinerja pegawai $(\mathrm{Y})$, dengan tingkat signifikansi $(\alpha)=5 \%$ dan degree of freedom $(\mathrm{df})=(\mathrm{n}-2)=132-2=130$ sehingga diperoleh $t_{\text {tabel }}$ 1.65666. Nilai sig. $(0,031)<\alpha$ $(0,05)$ dan $t_{\text {hitung }}(2,187)>t_{\text {tabel }}(1.65666)$ sehingga $\mathrm{H}_{0}$ ditolak. Dengan demikian terdapat pengaruh secara parsial motivasi kerja terhadap kinerja pegawai.

3. Pengaruh secara simultan Iklim Organisasi, Kompetensi Pegawai, dan Motivasi Kerja terhadap Kinerja Pegawai pada Balai Diklat Aparatur Kementrian Kelautan dan Perikanan Sukamandi.

Variabel iklim organisasi $\left(\mathrm{X}_{1}\right)$ mempunyai pengaruh langsung sebesar $8,7 \%$, pengaruh tidak langsung melalui hubungannya dengan kompetensi pegawai $\left(\mathrm{X}_{2}\right)$ sebesar $9,3 \%$, dan Pengaruh tidak langsung melalui motivasi kerja $\left(\mathrm{X}_{3}\right)$ sebesar 3,6\% Sehingga total pengaruhnya adalah sebesar 21,6\%. Variabel kompetensi pegawai $\left(\mathrm{X}_{2}\right)$ mempunyai pengaruh langsung sebesar $17,4 \%$, pengaruh tidak langsung melalui hubungannya dengan iklim organisasi $\left(\mathrm{X}_{1}\right)$ sebesar $9,3 \%$ dan pengaruh tidak langsung melalui Variabel motivasi kerja $\left(\mathrm{X}_{3}\right)$ sebesar $5,4 \%$, sehingga total pengaruhnya sebesar $32,1 \%$. Variabel Peran Kepemimpinan $\left(\mathrm{X}_{3}\right)$ mempunyai pengaruh langsung sebesar 3,2\%, sedangkan pengaruh tidak langsung melalui hubungannya dengan iklim organisasi $\left(\mathrm{X}_{1}\right)$ sebesar 3,6\% dan pengaruh tidak langsung melalui kompetensi pegawai $\left(\mathrm{X}_{2}\right)$ sebesar $5,4 \%$, sehingga total pengaruhnya sebesar $12,2 \%$. Hasil perhitungan Koefisien determinasi $\left(r^{2}\right)$ 
yang dinyatakan dalam persentase mengambarkan besarnya kontribusi semua variabel bebas yaitu iklim organisasi $\left(\mathrm{X}_{1}\right)$, kompetensi pegawai $\left(\mathrm{X}_{2}\right)$ dan motivasi kerja $\left(\mathrm{X}_{3}\right)$ dalam menentukan variasi Kinerja Pegawai (Y) adalah sebesar $\mathbf{6 5 , 9 \%}$. Sedangkan faktor lain yang tidak diteliti dan turut mempengaruhi Kinerja Pegawai pada Balai Diklat Aparatur Kementrian Kelautan dan Perikanan Sukamandi ditunjukan oleh nilai Py $\varepsilon=0,345$ atau sebesar $34,5 \%$

Untuk pengaruh iklim organisasi $\left(\mathrm{X}_{1}\right)$, kompetensi kerja pegawai $\left(\mathrm{X}_{2}\right)$, dan motivasi kerja $\left(\mathrm{X}_{3}\right)$ secara simultan (keseluruhan) terhadap kinerja pegawai (Y), dengan tingkat signifikansi $(\alpha)=5 \%$ dan degree of freedom $(\mathrm{df})$ $=(n-2)=132-2=130$ sehingga diperoleh $F_{\text {tabel }}$ 2,67 . Tabel di atas menunjukan nilai sig. $(0,00)<$ $\alpha(0,05)$ dan $F_{\text {hitung }}(81.150)>F_{\text {tabel }}(2,67)$ sehingga $\mathrm{H}_{0}$ ditolak. Dengan demikian dapat disimpulkan bahwa terdapat pengaruh secara simultan iklim organisasi, kompetensi pegawai, dan motivasi kerja terhadap kinerja pegawai.

\section{KESIMPULAN}

Berdasarkan hasil penelitian dan pembahasan, maka dapat diperoleh beberapa kesimpulan sebagai berikut:

1. Nilai hubungan Iklim organisasi dengan Kompetensi pegawai sebesar 0,751 menunjukan nilai kuat dan searah karena nilainya positif. Nilai hubungan variabel iklim organisasi dengan motivasi kerja sebesar 0,681 menunjukan nilai kuat dan searah karena nilainya positif. Nilai hubungan variabel kompetensi pegawai dengan motivasi kerja sebesar 0,722 menunjukan nilai kuat dan searah karena nilainya positif.

2. Hasil analisis jalur secara parsial pengaruh iklim organisasi terhadap kinerja pegawai sebesar 0,296, pengaruh kompetensi pegawai terhadap kinerja pegawai sebesar 0,417, dan pengaruh motivasi kerja terhadap kinerja pegawai sebesar 0,180 .

3. Pengaruh langsung iklim organisasi sebesar $8,7 \%$, pengaruh tidak langsung melalui kompetensi pegawai sebesar 9,3\%, dan pengaruh tidak langsung melalui motivasi kerja sebesar $3,6 \%$ Sehingga total pengaruhnya adalah sebesar $21,6 \%$. Pengaruh langsung kompetensi pegawai sebesar $17,4 \%$, pengaruh tidak langsung melalui iklim organisasi sebesar 9,3\% dan pengaruh tidak langsung melalui motivasi kerja sebesar 5,4\%, sehingga total pengaruhnya sebesar $32,1 \%$. Pengaruh langsung motivasi kerja sebesar 3,2\%, sedangkan pengaruh tidak langsung melalui iklim oorganisasi sebesar 3,6\% dan pengaruh tidak langsung melalui kompetensi pegawai sebesar 5,4\%, sehingga total pengaruhnya sebesar 12,2\%. Hasil perhitungan Koefisien determinasi $\left(\mathrm{r}^{2}\right)$ sebesar $\mathbf{6 5 , 9 \%}$. Sedangkan faktor lain yang tidak diteliti dan turut mempengaruhi Kinerja Pegawai pada Balai Diklat Aparatur Kementrian Kelautan dan Perikanan Sukamandi sebesar $34,5 \%$.

\section{REFERENSI}

Andarias Patiran. (2010). Analisis Faktor-Faktor Yang Mempengaruhi Kinerja Pegawai Negeri Sipil (PNS). Jurnal Ilmiah, 5(Kinerja).

Eddy Yunus. (2012). Pengaruh Kompetensi Sumber Daya Manusia Terhadap Kinerja Pegawai KPPBC Tipe Madya Pabean Tanjung Perak Surabaya.

Hamzah B. Uno. (2008). Teori Motivasi dan Pengukurannya. Bumi Aksara.

Henry Simamora. (2006). Manajemen Sumberdaya Manusia. Sekolah Tinggi Ilmu Ekonomi YKPN.

Islam, U., Sunan, N., Yogyakarta, K., Psikologi, F., \& Gadjah, U. (2015). Pengaruh Dukungan Sosial dan Kepemimpinan Transformasional Terhadap Komitmen Organisasi dengan Mediator Motivasi Kerja. Jurnal Psikologi, 37(1), 94-109. https://doi.org/10.22146/jpsi.7695

Mangkunegara, AA., P. (2006). Evaluasi Kinerja SDM. PT. Refika Aditema.

Ngalim Purwanto. (2006). Psikologi Pendidikan. PT Remaja Rosdakarya.

Prayitno, W. dan S. (2002). Standarisasi Kompetensi Pegawai Negeri Sipil Menuju Era Globalisasi Global. Pusat Penelitian Dan Pengembangan BKN, Volume II(Kompetensi Pegawai).

R. Palan. (2007). Competency Management. PPM.

T. Hani Handoko. (2001). Manajemen Personalia dan Sumber Daya Manusia. BPFE Yogyakarta.

Veithzal Rivai \& A.F.M Basri. (2005). Performance Appraisal. PT. Raja Grafindo Persada.

Wirawan. (2015). Manajemen Sumber Daya Manusia Indonesia. Rajawali Pers. 